\title{
Moult pattern of primaries and secondaries during first and second flight feather molt in Great Grey Owls Strix nebulosa
}

\author{
Mytemønster $i$ vingen hos lappugle Strix nebulosa etter første og andre \\ svingfjcermyting
}

ROAR SOLHEIM

\begin{abstract}
Great Grey Owls start flight feather moult when in their second year. Moult was studied on outspread wings of 58 individuals in the collections at Naturhistoriska Riksmuseet in Stockholm. The owls always moulted the innermost secondaries in their first moult, and usually at least two primaries, most often P5 and P6. After this moult, birds had 11-17 juvenile feathers left in each wing, of a total of 21 flight feathers. In their second flight feather moult, birds shed primaries outwards and inwards from the primaries moulted during the first moult. A variable number of secondaries outwards from S10 and S11 were moulted. All birds retained at least one juvenile feather, always P1. The number of juvenile flight feathers after

the second moult was $1-6$. The collection held no individuals known to be in their third flight feather moult. Thus it was not possible to determine whether birds in this age group could be aged by the wing moult pattern. Great Grey Owls with no juvenile flight feathers should thus be classified as $4 \mathrm{C}+$ in autumn, and $5 \mathrm{C}+$ in spring.

Roar Solheim, Agder Natural History Museum and Botanical Gardens, P.O. Box 1887, Gimlemoen, N-4686 Kristiansand.

Email: roar.solheim@kristiansand.kommune.no, r-solhe3@online.no
\end{abstract}

Received 2 March 2010, Accepted 18 March 2011, Editor: S. Svensson

\section{Introduction}

Very little is written on the moult of large feathers in owls. Mikkola (1983) does not cover this field, but in Cramp (1985) moult of flight feathers is described, mostly based on studies of captive birds. Moult is described for Little Owl Athene noctua, Tawny Owl Strix aluco, Long-eared Owl Asio otus and Short-eared Owl Asio flammeus in Baker (1983). The fact that Snowy Owls Bubo scandiacus and Eagle Owls Bubo bubo have 15 or more secondaries, opposed to the other owls which have 10 or 11 , is only mentioned by Cramp (1985) as far as I have discovered. Suopajärvi \& Suopajärvi (1994) described moult in Great Grey Owls, and Niiranen \& Haapala (1987) described moult in Eagle Owl, however both papers in Finnish, and thus not easily accessible.

Large owls and birds of prey do not moult all their flight feathers each year. They usually start moulting some primaries and secondaries in their second summer (second calendar year; 2C). Next year the moult continues, and the birds shed some of the older feathers. In their third moult (as 4C) or even later, the last juvenile feathers are usually lost in the largest species. Smaller species may moult all their flight feathers annually (as in Hawk Owl Surnia ulula; Cieslak \& Kwiecinski 2009), or partially (as in Tengmalm's owl Aegolius funereus; Cieslak \& Kwiecinski 2009, own data).

Through the year, feathers are bleached by sunlight and worn by use. When flight feathers are moulted partially each year, feathers of uneven age will look different in relation to colour, contrast, wear and tear. A pattern of dark and light feathers thus appears. However, the differences between feathers are not always easily observed, unless the bird's wings are examined in good light conditions (daylight or appropriate artificial light).

In some species juvenile flight feathers are distinctively different from older feathers, while in some others there is hardly any difference at all. When juvenile flight feathers are distinct, a bird may be aged quite accurately as long as such juvenile feathers are still present.

Based on work on Great Grey Owls Strix nebulo$s a$ in late autumn 2009 (Solheim 2009), I wanted to get a better insight into the moulting pattern of this 
great owl. This species moults a limited number of primaries and secondaries each year (Cramp 1985), thereby creating very distinct and visible moult patterns in the wings of older birds (see Solheim 2009, 2010). The best place for such studies in Scandinavia is Naturhistoriska Riksmuseet (NRM) in Stockholm. Here bird skins have been made for several decades with one wing loose and outstretched. This makes it possible to study all flight feathers without harming the skin itself. I was kindly allowed to visit the museum 12-15 January 2010, with access to the bird skin collections.

\section{Material and method}

I inspected all Great Grey Owls which had been prepared with at least one free wing. Each wing was photographed with the skin's catalogue number to reduce the risk of mix ups during later analyses of the material. Great Grey Owls have 10 primaries like the other owl species, 11 secondaries and three tertiaries. Tertiaries were not included in the analyses. The feathers were numbered starting from the carpal joint, in the same manner as described for Ural Owls Strix uralensis by Pietiäinen et al. (1984). The primaries and secondaries of each bird were described as being juvenile, old, new or dark. The last category was used for feathers distinctively different from juvenile feathers, but with too weak differences to be classified as old or new. Juvenile feathers were always easily recognized, because they have distinctly narrow terminal dark bands (see Figure 1). Wings where the contrast between feathers was not obvious, were also watched under UV-light in a dark room. The use of UV light greatly enhances the differences of new and old feathers, at least in some owl species (Solheim in prep.). Although new feathers did not light up under UV light as in owls with lighter feathers, in some cases the UV enhanced differences and underlined similarities between feathers of different and same generations.

Wings from 58 Great Grey Owls were photographed and described (see Appendix 1). For two specimens only the wings had been conserved, and both wings were checked for these two. The owls were recovered all year round, with slightly higher numbers originating from the months April (15), May (7) and October (6) (Table 1). They were classified as belonging to one of four age classes. Birds were classified as juveniles before they started their first flight feather moult in their second calendar year (2C). Juveniles thus include the age categories $1 \mathrm{C} \mathrm{A}$ (autumn) and 2C S (spring). M1 are birds in or after their first flight feather moult (2C A and 3C $\mathrm{S})$, and $\mathrm{M} 2$ are birds in or after their second moult (3C A and 4C S). Birds that have passed through three or more moult cycles, have been classified as $4 \mathrm{C}+$ in autumn, and $5 \mathrm{C}+$ in spring.

A total of 23 owls were ringed, either as pullus (13 ind.), as adults $2 \mathrm{~K}+(8)$ or with unknown data for time of ringing (2). Since the birds ringed as pullus can be categorized exactly at time of death, these birds have functioned as a blueprint for the moult pattern study. At time of death, the birds ringed as pullus were in age classes Juvenile (2), M2 (4) and older (7). No ringed birds were thus found in the M1 category. However, as the birds with the highest number of unmoulted juvenile feathers are found here, there is very little risk of

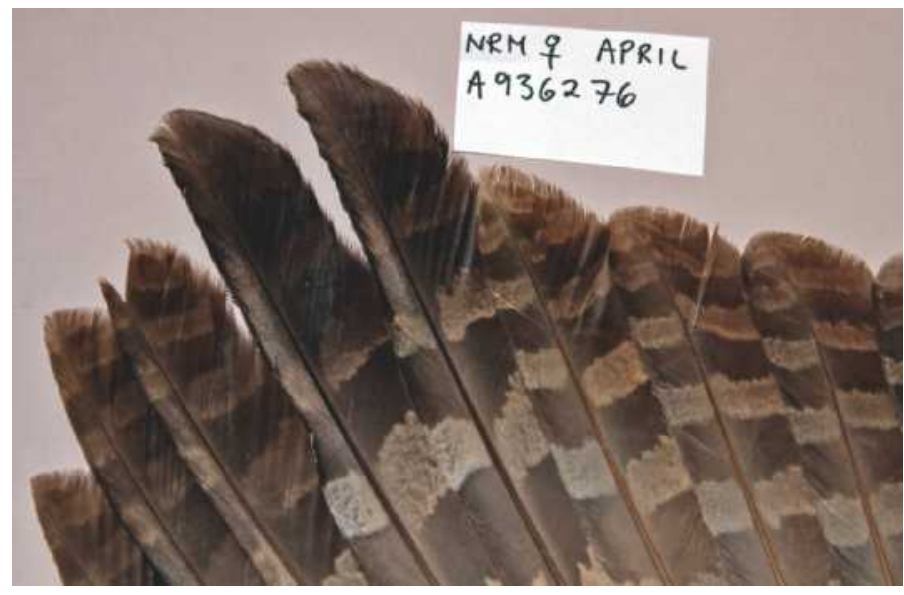

Figure 1. Detail of primaries on specimen 93/6276 from April 1993, showing distinct differences between juvenile and adult flight feathers (P5 and P6). Juvenile feathers are recognized by narrow, often unregular, terminal bands.

Detalj fra håndsvingfjoer på lappugle nr 93/6276 fra april 1993. De to lengste mørke fjarene er adulte fra siste sommers myting, og skiller seg tydelig fra de øvrige, juvenile fjcerene. De siste kjennes best på smale, ofte irregulcere, terminale trverrbånd. 
Table 1. Great Grey Owl wings in the collection of NRM, January 2010, showing month of recovery of specimen, and number of individuals in moult categories: Juvenile, M1, M2 and Older. For explanation, see text. Months with individuals in active moult (missing or growing flight feathers), and mean number of moult feathers in respective month is shown. * Individual not included in moult analyzes.

Lappugler, fordeling på måned funnet, samt alder i kategoriene Juv (1Kh, $2 K v), M 1$ (2Kh, 3Kv), M2 (3Kh, 4Kv), og eldre (4Kh og eldre). Måned med aktiv myting, og gjennomsnitt antall vingefjcer i myting per individ. * utelatt fra myteanalysen.

\begin{tabular}{|c|c|c|c|c|c|c|c|}
\hline \multirow[b]{2}{*}{ Month } & \multicolumn{5}{|c|}{ Moult category } & \multirow{2}{*}{$\begin{array}{l}\text { Ind. with } \\
\text { feathers in } \\
\text { growth }\end{array}$} & \multirow{2}{*}{$\begin{array}{l}\text { Mean no. of } \\
\text { flight feathers in } \\
\text { moult }\end{array}$} \\
\hline & Juv & M1 & M2 & Older & Sum & & \\
\hline January & & 1 & & 1 & 2 & & \\
\hline February & 1 & & 1 & 2 & 4 & & \\
\hline March & 1 & 1 & & 3 & 5 & & \\
\hline April & 2 & 4 & 3 & 6 & 15 & & \\
\hline May & & 2 & 3 & 2 & 7 & & \\
\hline June & & & $1 *$ & 2 & 3 & & \\
\hline July & & & 1 & 2 & 3 & 2 & 6.5 \\
\hline August & & & & 1 & 1 & 1 & 2 \\
\hline September & 1 & 2 & 1 & 1 & 5 & 4 & 2.5 \\
\hline October & 3 & 1 & & 2 & 6 & & \\
\hline November & & & 1 & 3 & 4 & 1 & 1 \\
\hline December & & 1 & & 2 & 3 & & \\
\hline Sum & 8 & 12 & 11 & 27 & 58 & & \\
\hline
\end{tabular}

placing these individuals in the wrong age category. This conclusion is supported by the described moult pattern (see later). The 7 individuals in the category older birds ranged from $6 \mathrm{C}$ to $17 \mathrm{C}$, the last individual being the oldest bird of known age in the material. Since there were no owls of documented 4CA or 5CS age, I have not tried to follow the moulting pattern after the second wing feather moult of the owls.

\section{Time of moult}

Eight birds were in active moult, with feathers either missing or growing (Table 1). These birds were recovered in July-September, with an exception of one bird in active moult of P3 found 14 November. Mean number of flight feathers in moult was 6.5 in July, 2 in August and 2.5 in September. Both birds moulting in July were females. However, the number of birds in active moult is too small to indicate any sex difference in moulting period.

\section{First moult M1}

Twelve individuals were classified as belonging to this category, with four 2CA birds and eight $3 \mathrm{CS}$ birds. The status of their flight feathers is shown in detail in Appendix 2. All individuals moulted at least one primary, but not more than three (mean 2.3-2.4; P6 and P7 of Jno 2008/6726 of uncertain status). Except for one bird, all moulted P5. Nine moulted P6, and 6 moulted P4. P1-P3, P9 and $\mathrm{P} 10$ were not moulted in any of these individuals. All birds moulted the innermost secondaries S10 and S11. In $75 \%$ S9 was moulted, and $50 \%$ of the birds also moulted S8 and S5. No birds moulted $\mathrm{S} 1$ and S3, and only a few moulted the rest of the secondaries. The birds moulted 4-10 flight feathers per wing (mean number 6.8-6.9; see above). This means that a Great Grey Owl after its first flight feather moult (2CA and 3CS) has a mean of 14.3 juvenile flight feathers left in each wing (span 1117). The moult pattern of a bird in this stage is thus easily recognized (see Figure 2).

\section{Second moult M2}

Eleven individuals were classified to this category, however one of these (Jno 97/6355) were left out from the analyses due to difficulties of correct numbering of the feathers. Two individuals were 3CA birds, and eight were 4CS birds. Four of the individuals were ringed as pullus, thus confirming their age. The detailed status of the moult patterns of the 10 birds are shown in Appendix 3.

Six of the birds had moulted primaries both out- 


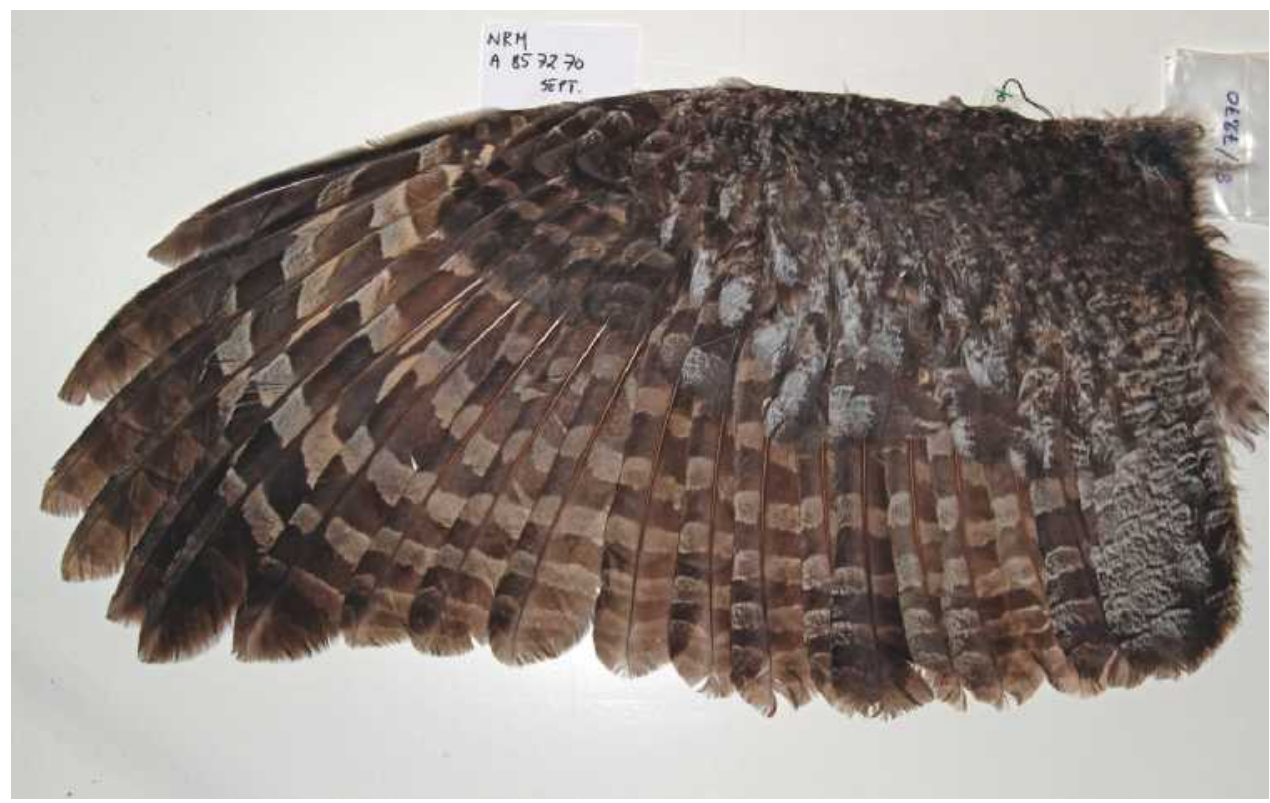

Figure 2. Typical wing pattern of a Great Grey Owl (specimen 85/7270) in stage M1, age 2C autumn. This bird has moulted the three primaries P4-P6, the innermost secondaries S9-S11, and S5.

Karakteristisk mytemønster hos lappugle i stadium M1 (alder 2Khøst). Fuglen har mytt håndsvingfjarene P4-P6, og armsvingfjcerene S9-S11, samt S5.

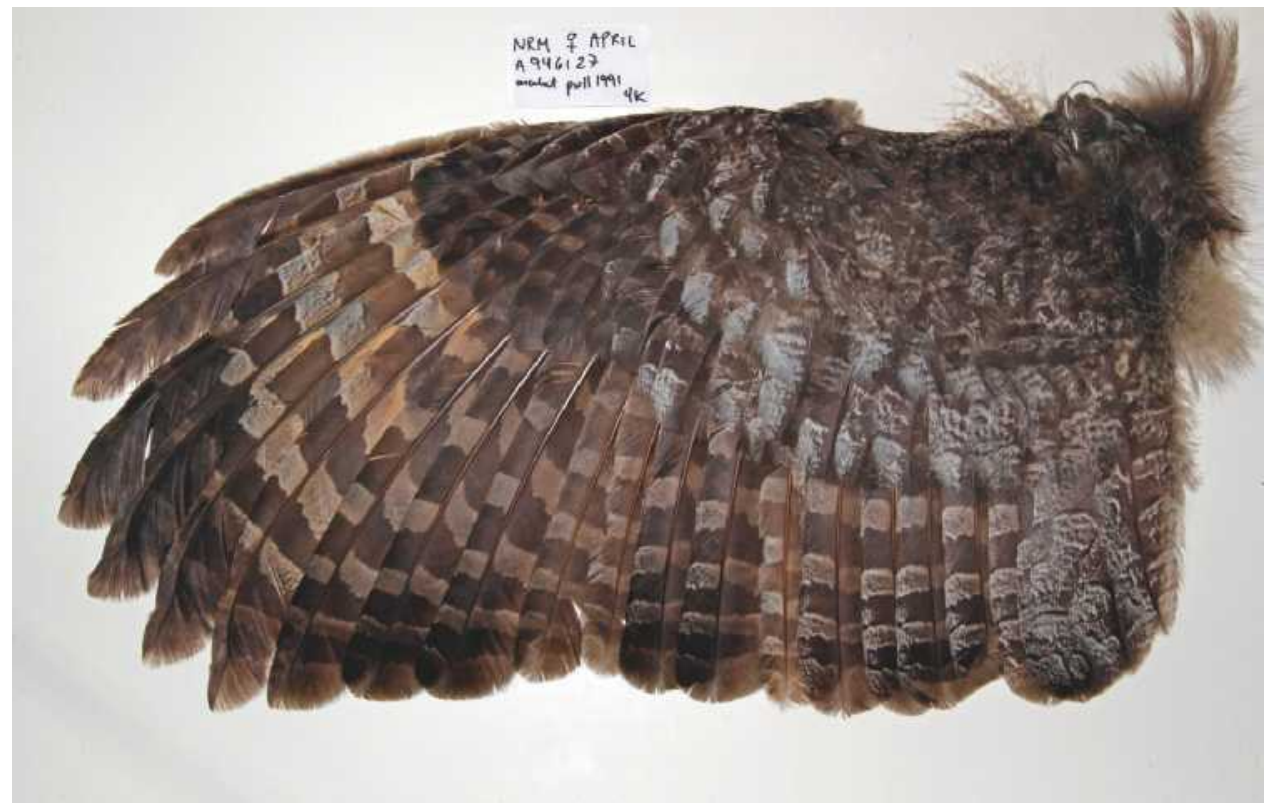

Figure 3. Typical wing pattern of a Great Grey Owl (specimen 94/6127) in stage M2, from April (age 4C spring). P2-P4, P7 and P8 were moulted last summer, P5 and P6 were moulted one year earlier, while P1, P9 and P10 are still juvenile, unmoulted feathers. For further explanation on the secondaries' pattern, see Appendix 3.

Karakteristisk mytemønster hos lappugle i stadium M2 (alder 4 Kvår). For noermere forklaring på mytemønsteret, se Appendix 3. 
wards and inwards from the primaries moulted the previous year. Most probably all individuals moulted like this, however for four birds the outermost primaries were only categorized as Dark, positively not juvenile feathers. All ten birds had moulted P5 during their previous, first flight-feather moult, and all birds moulted P3 during the second moult. Eight birds also moulted P4 in the second moult, while the two other birds had moulted this primary during their first moult. All birds retained at least one juvenile feather, and for all birds P1 was juvenile. The number of juvenile feathers ranged from 1-6 (mean number 3.4). Considering the 6 individuals in Appendix 3 with the least number of feathers in category D, the owls moulted 6-9 (7-13 if D-category feathers are considered new) flight feathers in their second moult (mean 7.3-10.3).

Because of added effect from individual variation in the number of feathers moulted during M1 and M2, the moult patterns of wings after the second moult (3CA) display considerable variation. In some birds the feathers from M1 and M2 were clearly different in darkness and wear, but in other individuals a considerable number of these feathers could only be classified as Dark (meaning positively non-juvenile). A typical wing of a bird in this category is shown in Figure 3.

\section{Discussion}

The moult patterns of Great Grey Owls as revealed by the skin material at NRM, are in accordance

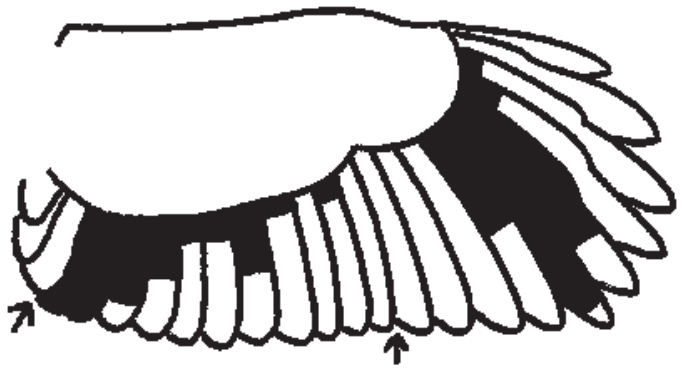

Figure 4. Schematised moulting pattern for the first flight feather moult in Great Grey Owl, based on 12 museum specimens. Black: new feathers, white: juvenile feathers. Proportion of black denotes probability for feather in that position to be moulted.

Skjematisert mytemønster for lappugle etter første svingfjormyting, basert på 12 museumseksemplarer. Sort: nye fjar, hvitt: juvenile fjcer. Mengden sort angir sannsynligheten for at en fjar i denne posisjonen har blitt skiftet. with the description given in Cramp (1985), with moult of primaries starting with P5 or P6. The number of Juvenile feathers in the wing after first and second moult does not overlap, and makes it quite easy to recognize these two age classes (Figure 4 and 5). Because there was no skin material available of Great Grey Owls of documented age in or after their third moult (4CA + 5CS), it is not possible for me to find the definitively end of presence of juvenile feathers. However, two ringed 6CS birds had no juvenile feathers left, and neither did any older birds. Juvenile feathers are thus always present at least until birds are in stage $4 \mathrm{CS}$, and seems never to be present after the fourth moult (M4). Until birds in stage 4CA $+5 \mathrm{CS}$ are studied in detail, Great Grey Owls with no juvenile feathers in their wings should be aged as $4 \mathrm{C}+$ in autumn, and $5 \mathrm{C}+$ in spring (January-June). This is in accordance with Suopajärvi \& Suopajärvi (1994), who state that the last juvenile flight feathers are moulted in the fourth or fifth calendar year of Great Grey Owls. According to these authours, the last juvenile flight feathers to be moulted are $\mathrm{P} 1$ or $\mathrm{P}$ 10 , and S 1 or S 4.

Great Grey Owls moult fewer flight feathers during their first moult than Ural Owls (see Pietiäinen et al. 1984). This may be because renewal of flight feathers is more energy demanding for large owls than for smaller owls. The moult cycle of the larger Eagle Owl seem to be even slower than in Great Grey Owls (Niiranen \& Haapala 1987, own studies). In Ural Owls the number of flight feathers

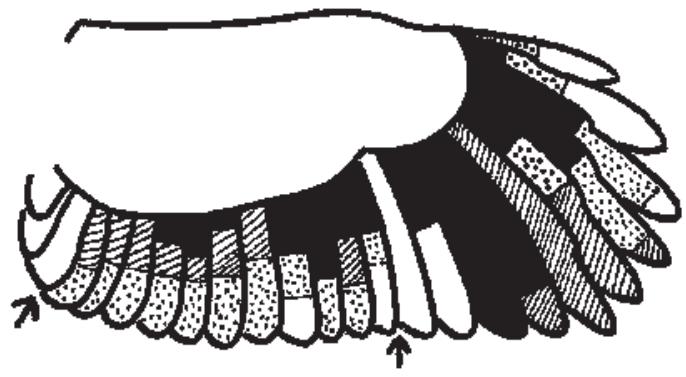

Figure 5. Schematised moulting pattern for the second flight feather moult in Great Grey Owl, based on 10 museum specimens. Black and white as in Figure 4, hatched: moulted during first moult, spotted: feather either new or from last moult, but positively not juvenile.

Skjematisert mytemønster for lappugle etter andre svingfjcermyting, basert på 10 museumseksemplarer. Sort og hvitt som på Figur 4, tverrstreket: byttet under første svingfjarmyting, prikket: fjoer fra første eller andre svingfjarmyting, men tydelig ikke-juvenil. 
moulted increase from M1 to M2, then drops from the second to the fifth moult, possibly because increased energy demands when birds enter breeding status (Pietiäinen op. cit.). Although the number of moulted feathers in M1 and M2 are lower in Great Grey Owls, this species too moult more flight feathers during M2 than during M1.These birds have probably not entered breeding status, and the more intense moult in 3C birds may reflect a general phenomenon, or maybe the fact that older birds are better hunters and thus in better condition than one year earlier.

The very distinctive moult patterns in Great Grey Owl wings in age categories 2CA-4CS are usually very easily detected on live birds from a distance, when they stretch their wings or fly. Modern digital photography makes it easy to capture and instantaneously analyze such images. The differences of owls make it possible to identify individual Great Grey owls during field observation (see Solheim $2009,2010)$. This owl species is a very good candidate for such field identifications, because Great Grey Owls display a high degree of acceptance to human observers. Being active during daylight, Great Grey Owls are often spotted by people in general, and by ornithologists in particular. As many ornithologists are also active bird photographers, it is possible to actively try to shoot images of their wings during flight, and thus build an identification archive as have been done for whales (see Hamilton et al. 2007) and large conspicuous terrestrial mammals.

\section{Acknowledgements}

I thank Naturhistoriska Riksmuseet in Stockholm for permission to study their collections of owl wings, and Göran Frisk in particular for finding material and providing data sheets of the skins. Also thanks to Tord Fransson for providing recovery data for ringed owls, and to Pertti Saurola who sent me information on Finnish papers on owl moult. The Norwegian Directorate for nature management provided funds to cover travel costs, of which I am very grateful.

\section{References}

Baker, K. 1993. Identification guide to European non-Passerines. BTO guide 24. British Trust for Ornithology, Thetford. 332pp.

Cieslak, M. \& Kwieschinski, Z. 2009. Moult and breeding of captive Northern Hawk Owls Surnia ulula. In: Johnson, D.H., Van Nieuwenhuyse, D. \& Duncan J.R. (eds). Proc. Fourth World Owl Conf. Oct-Nov 2007, Groningen, The
Netherlands. Ardea 97(4): 571-579.

Cramp, S. (ed) 1985. Handbook of the birds of Europe, the Middle East and North Africa. Vol. IV. Terns to woodpeckers. Oxford Univ. Press.

Hamilton, P.H., Knowlton, A.R. \& Marx, M.K. 2007. Right Whales tell their own stories: The photo-identification Catalog. In: The urban whale. North Atlantic Right Whales at the crossroads (Kraus, S.D. \& Rolland, R.M., eds). Harvard Univ. Press. 543 pp.

Mikkola, H. 1983. Owls of Europe. Poyser. 397 pp.

Niiranen, S. \& J. Haapala, J. 1987: Huuhkajan iän määrittäminen (Aging of Eagle Owl: Finnish language only). Lintumies 22: 112-116.

Pietiäinen, H., Saurola, P. \& Kolunen, H. 1984. The reproductive constraints on moult in the Ural Owl Strix uralensis. Ann. Zool. Fennici 21: 277-281.

Solheim, R. 2009. Lappugla - en klimaflyktning på vei sydover? Vår Fuglefauna 32: 164-169.

Solheim, R. 2010: Kan lappugglor individbestämmas utan infångande och märkning? Vår Fågelvärld 69 (2): 8-12.

Suopajärvi, P. \& M. Suopajärvi 1994: Lapinpöllön iän määrittäminen (Aging of the Great Grey Owl; finnish with English summary). Linnut 29 (2): 27-30.

\section{Opsummering}

Som hos andre store ugler myter lappuglene vingefjær partielt, dvs. de skifter bare noen av vingefjærene hvert år. De første vingefjærene mytes når fuglen er ett år gammel, dvs. 2K (i sitt andre kalenderår). Lappuglas første sett av vingefjær er tydelig forskjellige fra de fjærene som kommer etter, noe som gjør det mulig å gjenkjenne juvenile vingefjær. Naturhistorisk Riksmuseum i Stockholm har de beste samlingene i Norden for å studere fuglers mytemønster, fordi fugl gjennom mange år har blitt skinnlagt med en frilagt, utspent vinge. I januar 2010 besøkte jeg museet, og fotograferte og analyserte vinger fra 58 lappugler (Tabell 1, Appendix 1). Av disse var 23 individer ringmerket, derav 13 som reirunger. Mytemønsteret hos disse fuglene har fungert som fasit ved analysen av de øvrige lappuglenes mytemønster (karakteristiske mytemønster i Figurer 1-3).

Materialet omfattet 12 fugler etter første svingfjærmyting (2K.høst og 3K.vår; Appendix 2) og 10 fugler etter andre svingfjærmyting (3K.høst og 4K.vår; Appendix 3). Samlingen hadde ingen fugler med kjent alder etter tredje svingfjærmyting (4K.høst, 5K.vår), og mytemønster er derfor ikke forsøkt kartlagt etter andre svingfjærmyting. Etter første svingfjærmyting hadde alle lappuglene skiftet de innerste armsvingfjærene S11 og S10. De fleste fuglene hadde også skiftet minst to håndsvingfjær, vanligvis $\mathrm{P} 5 \mathrm{og} \mathrm{P} 6$. Etter første svingfjærmyting hadde fuglene i snitt 14.3 juvenile vingefjær tilbake i hver vinge (variasjon 11-17), av 
et totalt antall på 21 vingefjær. I sin andre svingfjærmyting skifter fuglene håndsvingfjær utover og innover fra de fjærene som ble skiftet året før. Et varierende antall armsvingfjær skiftes utover i vingen fra S10. Alle lappuglene hadde minst en juvenil svingfjær tilbake etter den andre svingfjærmytingen, og hos alle fuglene var P1 fremdeles juvenil. Antall juvenile svingfjær i vingen etter andre svingfjærmyting var i snitt 3.4 (variasjon 1-6). Mangelen på ringmerkte fugler med kjent alder $\mathrm{i}$ kategorien 4K.høst $/ 5 \mathrm{~K}$.vår umuliggjorde vurdering av om mytemønsteret kan følges hos lappugle etter den tredje svingfjærmytingen. Lappugler som helt mangler juvenile svingfjær (med hovedvekt på P1), bør derfor aldersklassifiseres som $4 \mathrm{~K}+$ på høsten, og $5 \mathrm{~K}+$ på våren.

Det tydelige mytemønsteret hos lappugler i alderskategoriene $2 \mathrm{~K}$.høst-4K.vår kan lett gjenkjennes på flygende fugler, eller på fugler som strekker den ene vingen (skjematiserte mytemønster i Figurer 4-5). Moderne digitalfotografering muliggjør en umiddelbar analyse av uglenes vinger. Forskjeller i mytemønster og fjærenes flekkmønster gjør det mulig å gjenkjenne lappugleindivider ute i naturen. Lappugla er en spesielt god kandidat for slik feltidentifisering, fordi fuglene vanligvis aksepterer mennesker som ikke kommer for nær. Som dagaktiv jeger observeres lappuglene raskt av mennesker generelt, og spesielt av ornitologer. Siden mange av dagens ornitologer også er gode fuglefotografer, kan en aktivt oppfordre alle til å forsøke å samle fotografier av lappuglenes vinger, og på den måten bygge opp et identifikasjonsarkiv slik man lenge har gjort for bestander av hvaler og store, lett observerbare, landlevende pattedyr.
Appendix 1.

Great Grey Owls in the collection of NRM photographed in this study. Museum journal number, date of recovery, classification in moult class and age at time of ringing for ringed individuals. Ages in bold: confirmed age of birds ringed as pullus. $\mathrm{K}=$ calendar year, $\mathrm{S}=$ Spring, $\mathrm{A}=$ Autumn.

Lappugler fra NRM fotografert $i$ dette mytestudiet. Museets journalnummer, dato for funn, alderskategori og alder ved merking for ringmerkte individer. Uthevet skrift: kjent alder.

\begin{tabular}{|c|c|c|c|c|c|c|}
\hline J.no NRM & Date & juv & M1 & M2 & Older & $\begin{array}{l}\text { Ringed } \\
\text { as }\end{array}$ \\
\hline $76 / 0191$ & 14.5 & & & $4 \mathrm{KS}$ & & \\
\hline $78 / 6043$ & 11.5 & & $3 \mathrm{KS}$ & & & \\
\hline $82 / 6418$ & 10.9 & & & 3KA & & pull. \\
\hline $84 / 6137$ & 12.2 & $2 \mathrm{KS}$ & & & & \\
\hline $84 / 6186$ & 25.3 & $2 \mathrm{KS}$ & & & & \\
\hline $84 / 6187$ & 19.3 & & & & $5 \mathrm{~K}+?$ & $2 \mathrm{~K}+$ \\
\hline $84 / 6370$ & 13.5 & & $3 \mathrm{KS}$ & & & $2 \mathrm{~K}+$ \\
\hline $85 / 6359$ & 31.3 & & $3 \mathrm{KS}$ & & & \\
\hline $85 / 6399$ & 5.4 & $2 \mathrm{KS}$ & & & & pull. \\
\hline $85 / 6957$ & 14.7 & & & & $5 \mathrm{~K}+$ & \\
\hline $85 / 7253$ & 16.9 & $1 \mathrm{KA}$ & & & & \\
\hline $85 / 7270$ & 22.9 & & $2 \mathrm{KA}$ & & & \\
\hline $85 / 7454$ & 16.10 & & $2 \mathrm{KA}$ & & & \\
\hline $85 / 7482$ & 22.10 & & & & $5 \mathrm{~K}+$ & \\
\hline $85 / 7600$ & 26.6 & & & & $6 K$ & pull. \\
\hline $86 / 6246$ & 7.4 & & & & $6 K$ & pull. \\
\hline $86 / 6284$ & 15.4 & & $3 \mathrm{KS}$ & & & \\
\hline $86 / 6319$ & 24.4 & $2 \mathrm{KS}$ & & & & \\
\hline $86 / 6321$ & 2.5 & & & $4 \mathrm{KS}$ & & \\
\hline $86 / 6379$ & 28.4 & & $3 \mathrm{KS}$ & & & \\
\hline $87 / 6203$ & 12.4 & & & $4 K S$ & & pull. \\
\hline $87 / 6235$ & 22.4 & & & & $5 \mathrm{~K}+$ & \\
\hline $87 / 6274$ & 9.4 & & & $4 \mathrm{KS}$ & & \\
\hline $87 / 6738$ & 14.11 & & & & $7 K$ & pull. \\
\hline $88 / 6144$ & 30.4 & & & & $8 K$ & pull. \\
\hline $88 / 6376$ & 8.5 & & & & $5 \mathrm{~K}+$ & $2 \mathrm{~K}+$ \\
\hline $89 / 6052$ & 16.2 & & & & $5 \mathrm{~K}+$ & \\
\hline $90 / 6536$ & 26.11 & & & & $5 \mathrm{~K}+$ & \\
\hline $91 / 6159$ & 7.5 & & & $4 \mathrm{KS}$ & & \\
\hline $91 / 6433$ & 14.6 & & & & $8 K$ & pull. \\
\hline $92 / 6125$ & 15.4 & & & & $4 \mathrm{~K}+$ & $2 \mathrm{~K}+$ \\
\hline $92 / 6224$ & 7.10 & $1 \mathrm{KA}$ & & & & \\
\hline $93 / 6276$ & 13.4 & & $3 \mathrm{KS}$ & & & \\
\hline $93 / 6911$ & 28.10 & & & & $5 \mathrm{~K}+$ & \\
\hline $93 / 6966$ & 16.11 & & & & $5 \mathrm{~K}+$ & \\
\hline $94 / 6127$ & 4.4 & & & $4 K S$ & & pull. \\
\hline $95 / 6048$ & 9.2 & & & $4 \mathrm{KS}$ & & \\
\hline $95 / 6104$ & Apr & & & & $5 \mathrm{~K}+$ & \\
\hline $95 / 6140$ & 19.12 & & & & $5 \mathrm{~K}+$ & \\
\hline $95 / 6141$ & 26.3 & & & & $5 \mathrm{~K}+$ & \\
\hline $95 / 6312$ & 2.7 & & & & $5 \mathrm{~K}+$ & $2 \mathrm{~K}+$ \\
\hline $95 / 6465$ & Nov & & & $3 \mathrm{KA}$ & & \\
\hline $95 / 6533$ & Dec & & $2 \mathrm{KA}$ & & & \\
\hline $96 / 6332$ & 20.5 & & & & $12 K$ & pull. \\
\hline $97 / 6080$ & 3.3 & & & & $17 K$ & pull. \\
\hline $97 / 6107$ & 2.4 & & $3 \mathrm{KS}$ & & & \\
\hline $97 / 6355$ & 19.7 & & & $3 \mathrm{KA}$ & & ? \\
\hline $2000 / 6024$ & 10.1 & & $3 \mathrm{KS}$ & & & \\
\hline 2000/6086 & 3.9 & & & & $5 \mathrm{~K}+$ & \\
\hline $2001 / 6256$ & 18.6 & & & $4 K S$ & & pull. \\
\hline $2002 / 6458$ & 9.10 & $1 \mathrm{KA}$ & & & & \\
\hline $2003 / 6153$ & 10.2 & & & & $5 \mathrm{~K}+$ & \\
\hline $2004 / 6425$ & 13.4 & & & & $12 K+$ & $3 \mathrm{~K}+$ \\
\hline $2005 / 6512$ & 29.10 & $1 \mathrm{KA}$ & & & & pull. \\
\hline $2005 / 6516$ & 31.8 & & & & $5 \mathrm{~K}+$ & $2 \mathrm{~K}+$ \\
\hline $2008 / 6726$ & 17.9 & & $2 \mathrm{KA}$ & & & \\
\hline $2009 / 6006$ & 3.1 & & & & $8 \mathbf{K}+$ & $2 \mathrm{~K}+$ \\
\hline $2009 / 6013$ & 22.12 & & & & $5 \mathrm{~K}+$ & \\
\hline
\end{tabular}




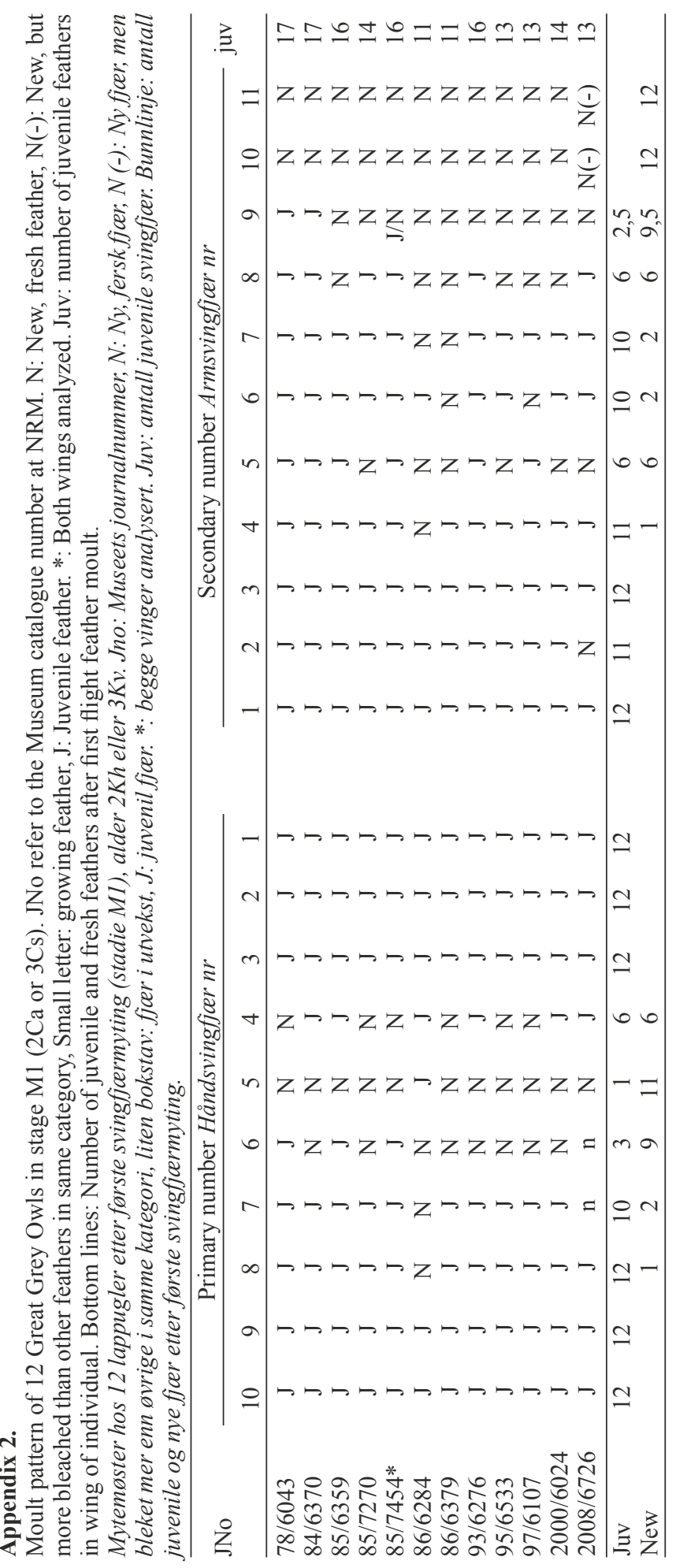




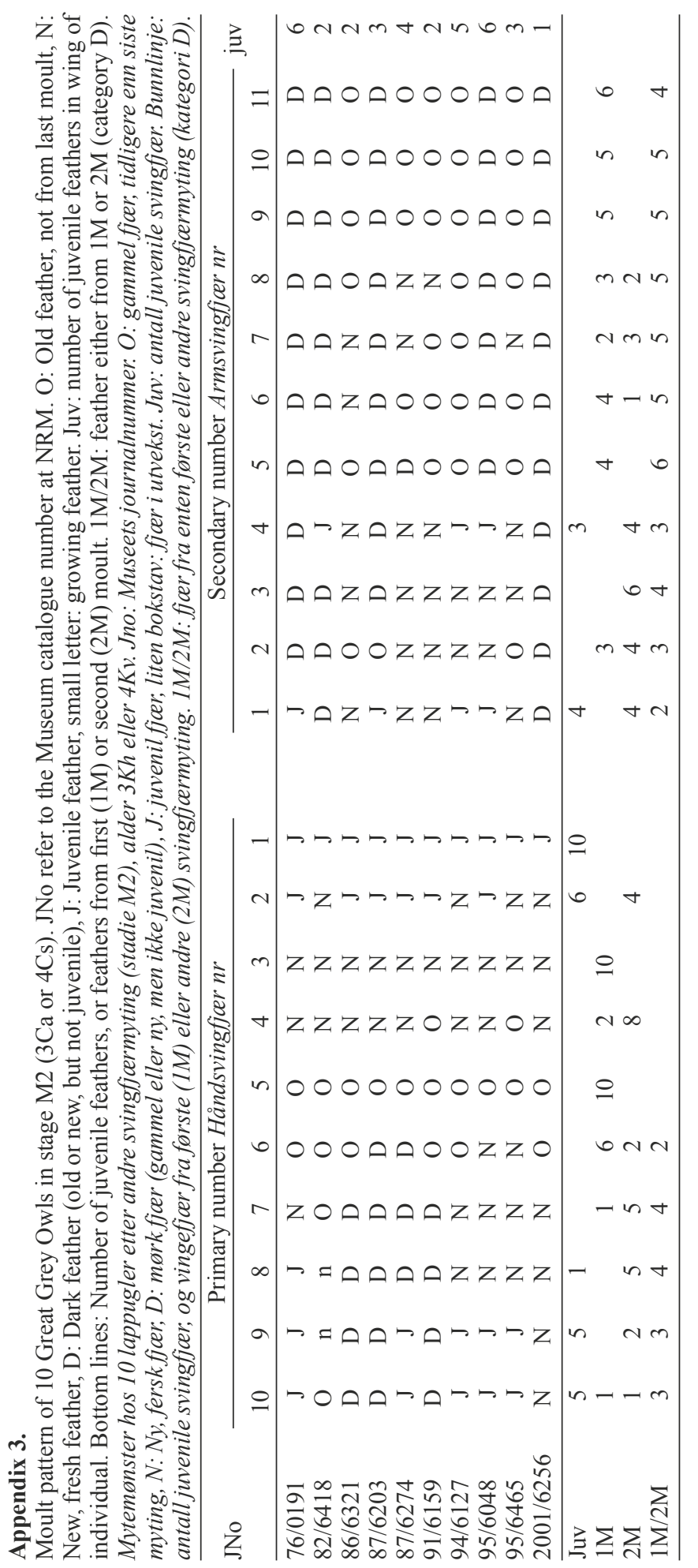

